\title{
PHYSICAL CHARACTERISTICS OF PASSIONFRUIT CV. BRS GIGANTE AMARELO PRODUCED BY FLOWERS WITH THREE AND FOUR CARPELS
}

\author{
CARACTERÍSTICAS FÍSICAS DOS FRUTOS DE MARACUJAZEIRO-AZEDO CV. \\ BRS GIGANTE AMARELO PRODUZIDOS POR FLORES COM TRES E QUATRO \\ CARPELOS
}

\author{
Danilo Akio de Sousa ESASHIKA ${ }^{1}$; Fábio Gelape FALEIRO² \\ Nilton Tadeu Vilela JUNQUEIRA ${ }^{2}$ \\ 1. Eng. Agrônomo, Doutor pelo Programa de Pós-Graduação em Agronomia - PGA, da Universidade de Brasília, \\ daniloakio09@hotmail.com. 2. Eng. Agrônomos, Pesquisadores da Embrapa Cerrados, Planaltina, DF, ffaleiro@cpac.embrapa.br, \\ junqueir@cpac.embrapa.br
}

\begin{abstract}
The carpel is the female reproductive structure composed of a set of stigma, style and ovary. Normally passionflower have three carpels, however, some cultivars have this structure in greater quantity. The objective of this work was to identify relationships between the number of carpels and the physical characteristics of BRS Gigante Amarelo fruits. The flowers with three and four carpels were marked, pollinated and the fruits harvested from these flowers analyzed for transverse diameter, longitudinal diameter, pericarp thickness, fruit mass, pulp mass, pulp ratio, number and weight of seeds. A completely randomized design with 10 replicates per treatment was used and each plot had the average of 3 fruits. The data were submitted to variance analysis and the means were compared by the Tukey test at $5 \%$ of probability. The fruits generated by flowers with 4 carpels were $18,30 \%$ heavier, their pulp were on average $20.75 \%$ heavier, presented transverse diameter $7,53 \%$ superior to that of fruits generated by flowers with 3 carpels. Similar increments were identified regarding the number of seeds and the weight of seeds per fruit that increased $18,85 \%$ and $52.42 \%$, respectively. This result indicates that cv. BRS Yellow Giant with 4 carpels generates heavier fruits, pulp and seeds with a more spherical shape.
\end{abstract}

KEYWORDS: Passiflora. Plant breending. Flower biology.

\section{INTRODUCTION}

The species of passionfruit belong to the Passifloraceae's Family, which is composed by 36 kinds and, among them, the Passiflora kind is the one that presents more importance with 534 accepted species (THE PLANT LIST, 2013; FLORA DO BRASIL, 2016). The sour passionfruit, known as yellow passionfruit (Passiflora edulis Sims) as well, is the most cultivated species in Brazil. This species have public and private genetic improvement programs spread across the country, which has the main purpose of generate more productive and more resistant cultivars to diseases and pests (FALEIRO; JUNQUEIRA; BRAGA, 2005).

Increase the productivity is always one of the main goals of the agricultural scientists, which is essential to the growth of the passionfruit in Brazil (MELETTI, 2011). For this reason, the process of identification of Passiflora individuals that present characteristics that contribute to improve the productivity is highly needed to the genetic improvement programs and, specially, to the entire productive chain of passionfruit. Regarding this matter, there is a belief that the number of carpels of the flower is associated with the fruit's size and mass, since the fruit of the Passiflora kind comes from the bloom of the ovary after the fecundation of the ovule.

The majority of passiflora presents flowers with three sets of styles and stigmas that begin in the upper center of the unilocular ovary with three parietal placentas (CERVI, 1997). Although, there are individuals of $P$. edulis that presents flowers with four sets of parietal placentas, styles and stigmas. Knowing that each set form one carpel.

The studies that correlate the floral morphology and the physical characteristics of the passionfruit are still incipient and with an original nature. Therefore, it is a promising field of study that may generate cultivars more productive and with bigger fruits. It is believed that this correlation has an effect of the population of genetic improvement and as well of the individuals or cultivars analysed. 
Physical characteristics of passionfruit...

The objective of this work was sought to evaluate the influence of the number of the flower's carpels in the fruit quality of the Passiflora edulis Sims cv. BRS Gigante Amarelo (BRS GA1).

\section{CONTENTS}

The experiment was made in the year of 2017, in a greenhouse localized at the Núcleo Rural Pipiripau, in the city of Planaltina-DF (Brazil), inside a region with AW Tropical climate, according to the Köppen's classification.

It was used the BRS Gigante Amarelo cultivar handled in espaliers of one wire and with management of fertilization and pest and diseases control, in accordance with the suggested instructions to this cultivar. Flowers with three and four carpels were pollinated manually and tagged to the subsequent harvest of its fruits.

The measured characteristics in each fruit were: fruit mass, pulp mass with seed, transverse diameter, longitudinal diameter, pericarp thickness, quantity and mass of the seeds.

The experiment was performed by a completely randomized design with 10 repetitions per treatment and each one of them was composed by an average of three fruits. The data was subjected to analysis of variance and the averages were compared by the Tukey test (5\% of significance).
SASHIKA, D. A. S. et al.

Besides that, it was calculated the Pearson correlation coefficient amongst the characteristics of the evaluated fruits.

It was noticed meaningful effects of the number of carpels to the following variables: transversal diameter $(\mathrm{F}=15,62 ; \mathrm{p}=0,0012)$, pulp mass $(F=6,636 ; p=0,0202)$, fruit mass $(F=7,945$; $\mathrm{p}=0,011)$, quantity of seeds $(\mathrm{F}=7,30 ; \mathrm{p}=0,0139)$ and mass of seeds $(F=30,84 ; p=0,0001)$. Such effects were not founded in the following variables: longitudinal diameter, pericarp thickness and pulp ratio (Table 1 ).

This result indicates that the number of carpels from a BRS Gigante Amarelo flower is directly connected with the growth of fruits with more total mass and pulp mass. Furthermore, it is also connected with a larger number of seeds and heavier seeds. Similar results were found by Siqueira et al. (2009) that observed that the fruits coming from four carpels flowers pollinated manually have shown diameters, pericarp thickness, mass and number of seeds superior to the fruits coming from a three carpels flower.

The average mass of fruits coming from four carpels flowers was 18,30\% higher than the fruits coming from three carpels flowers. It was noticed as well an improvement of $20,75 \%$ in the average pulp mass (Table 1).

Table 1. Physical characteristics of passionfruits from flowers with 4 and 3 carpels, Planaltina-DF, 2017.

\begin{tabular}{llll}
\hline \multirow{2}{*}{ Characteristics } & \multicolumn{2}{l}{ Number of carpels } & $\begin{array}{l}\text { Difference between } 4 \text { and } 3 \\
\text { carpels (\%) }\end{array}$ \\
\cline { 2 - 4 } & 4 & 3 & $+7,53$ \\
Ø Transversal $(\mathrm{cm})$ & $9,42 \pm 0,40 \mathrm{a}$ & $8,76 \pm 0,39 \mathrm{~b}$ & $+1,91$ \\
$\varnothing \quad$ Longitudinal & $10,70 \pm 0,44 \mathrm{a}$ & $10,50 \pm 0,08 \mathrm{a}$ & $+2,00$ \\
$(\mathrm{~cm})$ & $0,51 \pm 0,07 \mathrm{a}$ & $0,50 \pm 0,08 \mathrm{a}$ & $+20,75$ \\
Pericarp $(\mathrm{cm})$ & $180,33 \pm 32,62 \mathrm{a}$ & $149,34 \pm 19,91 \mathrm{~b}$ & $+18,30$ \\
Pulp mass $(\mathrm{g})$ & $353,87 \pm 34,44 \mathrm{a}$ & $299,13 \pm 26,58 \mathrm{~b}$ & $+3,85$ \\
Fruit mass $(\mathrm{g})$ & $0,54 \pm 0,03 \mathrm{a}$ & $0,52 \pm 0,03 \mathrm{a}$ & $+18,85$ \\
Pulp Ratio \% & $506,57 \pm 69,70 \mathrm{a}$ & $426,23 \pm 63,04 \mathrm{~b}$ & $+52,42$ \\
Quantity of seeds & $23,90 \pm 3,40 \mathrm{a}$ & $15,68 \pm 3,21 \mathrm{~b}$ & \\
Seeds mass $(\mathrm{g})$ & &
\end{tabular}

* Averages in the same line followed by the same letter do not differentiate statically between themselves according with the Tukey test at $5 \%$ of significance.

The results obtained during the experiment may be explained by the existence of one more placentation in the ovary of four carpels flowers (Figure 1). The existence of one additional placentation causes a larger amount of seeds and, consequently, it causes a greater quantity of pulp in the fruit. The fact is clear when it is considered that the generated fruits, coming from four carpels flowers, have shown increase of $18,85 \%$ in the number of seeds and $52,42 \%$ in the mass of seeds per fruit.

The enhancement of the number of seeds in the fruit is related to a larger number of egg cells presents in the additional placentation inside the ovary (Figure 1). Siqueira et al (2009) have observed that, in flowers with 3 carpels, the average quantity of egg cells was $462 \pm 55,1$, while flowers 
with 4 carpels have presented in average $674,5 \pm$ 105,7 ovules.

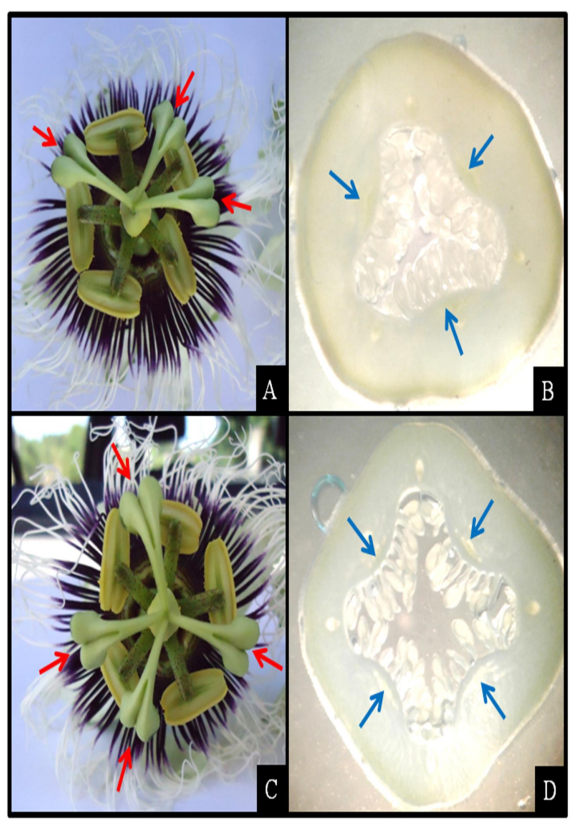

Figure 1. Flowers and ovary of passionfruit plants with 3 (A e B) and 4 (C e D) carpels.

The red arrows indicates sets of stigmas and styles. The blue arrows indicate the number of placentation inside the ovary.

At field, the four carpel flowers are easily identified by the larger amount of sets of stigmas and styles (Figure 1). Besides the fact that the ovary of flowers with 4 carpels presents itself slightly more rounded than the ovary of flowers with 3 carpels, in order to identify that the ovary has four carpels, it is necessary to do a transversal cut of the ovary and identify the existence (or not) of one additional placentation (Figure 1).

The shape of the fruit was influenced by the presence of one additional carpel in the flowers, since passionfruits coming from four carpels flowers have shown an increase of $7 \%$ in the transversal diameter in comparison with those fruits produced by flowers with 3 carpels. Besides that, fruits from four carpels flowers presented more rounded shape and superior characteristics for fresh fruit commercialization.

The longitudinal diameter and the pericarp thickness of the passionfruit have not shown any meaningful difference, between the fruits from 4 carpels flowers and 3 carpels flowers. Those results evidenciates the fact that the number of carpels not reduced the longitudinal diameter, besides of having increased the transversal diameter and also not handicapped the pulp ratio through the thickening of the fruit pericarp. As it is possible to see in Table 1, the difference between the pulp ratio of these kinds of fruits is not significant.
It was observed a positive correlation between the fruit mass and the transversal diameter, longitudinal diameter, pulp mass and seeds mass (Table 2). It is highly notable as well the significant correlation between the pulp mass and the transversal diameter, corroborating with the results presented in Table 1.

Therefore, it was observed that the increase of number of carpels causes an increase in transversal diameter, fruit mass, pulp mass and seeds mass as well.

Considering that the BRS Gigante Amarelo cultivar has shown average productivity of 42 tons per hectare in the first year of harvesting (EMBRAPA, 2008), an possible enhancing of $18,30 \%$ in its productivity and $20,75 \%$ in its pulp mass clearly shows an evident potential that the flower with 4 carpels has, which may improve the current cultivar, the passionfruit production and, consequently, it also may improve the rural producer income.

To P. edulis cultivar BRS Gigante Amarelo, fruits generated by flowers with 4 carpels have shown a significant increase in its transversal diameter, fruit and pulp mass, number of seeds and seeds mass. 
Table 2. Phenotypic correlation matrix between the physical characteristics of fruits from 3 and 4 carpels flowers, Planaltina-DF, 2017.

\begin{tabular}{ccccccccc}
\hline Variable & $\begin{array}{c}\varnothing \\
\text { Transversal }\end{array}$ & $\begin{array}{c}\varnothing \\
\text { Longitudinal }\end{array}$ & Thickness & $\begin{array}{c}\text { Fruit } \\
\text { mass }\end{array}$ & $\begin{array}{c}\text { Pulp } \\
\text { mass }\end{array}$ & Pulp ratio & $\begin{array}{c}\text { Number } \\
\text { of seeds }\end{array}$ & $\begin{array}{c}\text { Seeds } \\
\text { mass }\end{array}$ \\
\hline$\varnothing$ Transversal & 1 & --- & --- & --- & --- & --- & & \\
$\varnothing$ & 0.40 & 1 & --- & --- & --- & --- & & \\
Longitudinal & 0.19 & 0.19 & 1 & --- & --- & --- & & \\
Pericarp & $0.74^{*}$ & $0.31^{*}$ & 0.53 & 1 & --- & --- & & \\
Fruit mass & $0.66^{*}$ & 0.14 & 0.38 & $0.94^{*}$ & 1 & --- & & \\
Pulp mass & 0.10 & -0.35 & -0.18 & 0.22 & 0.54 & 1 & & \\
Pulp ratio & 0,43 & 0,20 & 0,33 & 0,46 & 0,49 & 0,29 & 1 & \\
Number of & & 0,15 & 0,05 & 0,54 & 0,58 & 0,35 & $0,71^{*}$ & 1 \\
$\quad$ seeds & $0,70^{*}$ & 0,58 & & & &
\end{tabular}

${ }^{*} \mathrm{p}<0,001$.

RESUMO: O carpelo é a estrutura reprodutiva feminina composta por um conjunto de estigma, estilete e ovário. Normalmente as flores de maracujá possuem três carpelos, porém, algumas flores de algumas cultivares apresentam essa estrutura em maior quantidade. Neste trabalho, objetivou-se identificar relações entre o número de carpelos e as características físicas dos frutos da cultivar BRS Gigante Amarelo. Flores com três e quatro carpelos foram marcadas, polinizadas e os frutos colhidos a partir destas flores foram analisados quanto ao diâmetro transversal, diâmetro longitudinal, espessura do pericarpo, massa do fruto, massa da polpa, rendimento de polpa, número e massa das sementes. Foi utilizado o delineamento inteiramente casualizado com 10 repetições por tratamento sendo cada parcela a média de 3 frutos. Os dados foram submetidos a análises de variância e as médias foram comparadas pelo teste de Tukey a 5\% de probabilidade. Os frutos gerados por flores com 4 carpelos foram 18,30\% mais pesados, sua polpa foi em média $20,75 \%$ mais pesada, apresentaram diâmetro transversal 7,53\% superior, ao de frutos gerados por flores com 3 carpelos. O mesmo acréscimo foi identificado quanto ao número de sementes e a massa das sementes por fruto que aumentaram $18,85 \%$ e $52,42 \%$, respectivamente. Este resultado indica que flores da cv. BRS Gigante Amarelo com 4 carpelos geram frutos, polpa e sementes mais pesados com formato mais arredondado.

PALAVRAS-CHAVE: Passiflora. Melhoramento genético. Biologia floral.

\section{REFERENCES}

CERVI, A. C. Passifloraceae do Brasil: estudo do gênero Passiflora L. subgênero Passiflora.

Fontqueria, Madrid, v.45, n. 1, p. 1-92, jul. 1997.

EMBRAPA. Notícias. 2008. Empresa Brasileira de Pesquisa Agropecuária. Available in: https://www.embrapa.br/noticias. Access at: 30 jun. 2011.

FALEIRO, F. G.; JUNQUEIRA, N. T. V.; BRAGA, M. F. Germoplasma e melhoramento genético do maracujazeiro - desafios da pesquisa. In: FALEIRO, F.G.; JUNQUEIRA, N.T.V.; BRAGA, M.F. (Eds.) Maracujá: germoplasma e melhoramento genético. Planaltina, DF: Embrapa Cerrados, 2005. p. 187-210.

FLORA DO BRASIL. Passiflora in Flora do Brasil 2020. Jardim Botânico do Rio de Janeiro. Available in: <http://floradobrasil.jbrj.gov.br/reflora/floradobrasil/FB12506>. Access at: 20 dec. 2016. 
MELETTI, L. M. M. Avanços na cultura do maracujá no Brasil. Revista Brasileira de Fruticultura, Jaboticabal, v. 33, n. 1, p. 83-91, oct. 2011. https://doi.org/10.1590/S010029452011000500012

SIQUEIRA, K. M. M.; KILL, L. H. P.; MARTINS, C. F.; LEMOS, I. B. Ecologia da polinização do maracujá-amarelo, na região do vale do submédio São Francisco. Revista Brasileira de Fruticultura, Jaboticabal, v. 31, n. 1, p. 1-12, mar. 2009. https://doi.org/10.1590/S010029452009000100003

THE PLANT LIST. The Plant List. Version. 1.1, 2013. Available in: http://www.theplantlist.org/. Access at: 20 dec. 2016. 